\title{
The Nyambai Culture in Coastal Communities: A Relationship to the Concept of Functions, Forms and Meanings
}

\author{
F Daryanti ${ }^{1}$, M Jazuli ${ }^{2}$, T Sumaryanto ${ }^{3}$, Hartono $^{4}$ \\ ${ }^{1}$ Universitas Lampung, Lampung, Indonesia. \\ ${ }^{1-4}$ Doctoral Student of Universitas Negeri Semarang, Indonesia \\ ${ }^{2-4}$ Universitas Negeri Semarang, Semarang, Indonesia.
}

E-mail: vtridaryanti@gmail.com

\begin{abstract}
Nyambai culture is one of the cultures infatuated by the Saibatin indigenous people in the West Coast region of Lampung. As a culture The coastal culture attracts many influences from outside, it were especially influenced by Chinese, Arabic and Dutch cultures. This research reveals how to understand the relation of the concept of function, form and meaning of flogging culture to indigenous peoples living in coastal areas. The purpose of this study was to find out about the extent to which the Nyambai culture could influence the pattern of people life in the coastal areas. This study uses a structuralism approach to express the phenomenon of the relation of the concept of Nyambai cultural functions. The type of research and approach used is descriptive qualitative, which describes each cultural phenomenon that is directly related to the culture of society. The data collection technique is done through observation, interviews, and document studies. The findings of this study indicate that, the function, form, and meaning of the flogging culture implicitly or explicitly influence the pattern of human action in everyday life, maintaining the relationship between humans and God, with nature, and with each other. As a form of cultural acculturation, Nyambai is a new identity for art forms in the Coastal region.
\end{abstract}

Keywords: Nyambai Culture; Acculturation of Culture; Coastal Communities. 


\section{INTRODUCTION}

Culture is an important part of human life, culture is created and used for the benefit of humans in everyday life. Nyambai is one form of local wisdom that is owned by the Lampung Saibatin indigenous people who live in the Coastal area, created and utilized by the community for the benefit of traditional event activities [1],[2]. Nyambai can be said as a traditional event, it can also be called a performance event, because Nyambai is one of the special events held for young people and girls in the community in the form of artistic activities. As a form of Coastal culture, the culture of flogging is influenced by ecological factors. Ecological factors, in general namely, the culture of the community can be divided into two, Coastal culture, namely people residing in areas along the coastline and agrarian culture, namely people who live in rural areas. Both types of society have different cultural characteristics, these differences are found in the resources faced [3].

Ecologically, the life patterns of the Saibatin indigenous people who live in the West Coast of Lampung are not only influenced by aquatic culture and plantations, this is due to the location of adjacent territories between the sea and forests, ecological factors provide a strong role in the development of human culture within society which is also influenced by natural resources, culture and the community environment both of which are interconnected and influence each other. All aspects of culture which are the work of human beings are functionally interrelated. Some studies on culture in the Coastal community include; Coastal culture is the spearhead of globalization [4], the uniqueness of children's visual expression is influenced by the ecological environment [5], art as a form of gratitude to the rulers of the sea [6], the influence of Islamic, Malay, and Chinese culture, resulting in archipelagic Islamic art, the communication style of coastal communities is the equalitarian style and the relinquishing style [7]. Coastal Culture is a picture of the chain of trade, social interaction, political relations and literary and artistic interactions [8]. From this study it seems that culture and environment have a strong influence on the sustainability and sustainability of community life.

How the Lampung community in the Coastal environment interacts with nature and the environment, to what extent the environment influences their socio-cultural life, this research is very important to explain the relationship between a group of Saibatin communities or indigenous people who use the environment for the sake of survival. This research was also conducted to explain the interrelation of a region with other regions, one culture and culture that influenced it. Thus this research on Nyambai culture is very important to be done to find out the relation between the concept of function, the form and meaning of the waving culture for the people in the coastal environment. Furthermore, this research was carried out by aiming to understand the relation of the concept of function, form and meaning of flogging culture, this is very important because to know the cultural identity of the people must see any culture that is the background and influence it as cultural capital. Therefore, the results of this study are expected to be self-reflection and even reflection on immigrant communities to know, recognize and learn forms of traditional Lampung arts, especially artistic identity in Coastal culture.

\section{METHOD}

This study uses a structural approach that examines the use of elements in the Nyambai culture. This research can be categorized as a qualitative research paradigm procedure, analysis of the text and socio-cultural context of the community based on environmental influencing factors and the descriptive and interpretative process of attachment are based on empirical 
evidence found in Nyambai cultures. This study was conducted in the West Coast of Lampung. The analysis technique uses the interactive work model Milles \& Huberman [9] which consists of three components, namely data reduction, data presentation, and verification. Data collection techniques in this study were observation, interviews, and document studies. Data sources were taken from elements of the waving cultural show. Data collection used in this study is the study of documents, analyzing the elements of performance, and clarifying with literature.

\section{RESULTS AND DISCUSSION}

Coastal culture has an open, democratic and tolerant nature. Based on its historical aspects, Coastal communities since ancient times have been pluralistic communities due to shipping, trade and other cultural political relations. The West Coast region of Lampung, especially in the Krui area, is synonymous with a transit point for merchant ships, as evidenced by the presence of the Kuala Stabas port in the Dutch era entering Krui. Coastal Area is a dynamic and always open civilization for change, the relationship between culture and ecology is one of the focuses of this research. Using an ecological approach, this paper seeks to find connections between the Saibatin indigenous people and their environment.

The Saibatin indigenous people in the cultural system have unique customs, the culture of the community is reflected in every customary event held. One of them is the Nyambai culture that is identical to the traditional wedding ceremony or the community calls it Nayuh. The culture of Nyambai in living and developing in the coastal region has a lot of influence from outside, including Chinese, Arabic, Dutch culture. While Lampung culture itself is still closely related to Malay culture, so there are some similarities with the Malay family. The influences of outside culture that are very influential in the culture of society, especially in their art form. The influence of external culture mingles with Lampung culture so that there is a process of cultural acculturation, which can be seen from the culture of flirting.

\subsection{Acculturation of Waving Culture}

Coastal communities that have a very open attitude towards dating culture will have implications for the formation of new cultures through a process of acculturation of cultures, immigrant cultures that enter the Coastal region will eventually familiarize and contour new cultures. The waving culture born in the coastal and land environment is a manifestation of the pattern of human action and the social structure of society in shaping its cultural characteristics. The external cultural influences that affect the culture of the Nyambai are as follows:

a. Malay Culture

Lampung communities on the coast are also called having the same or allied clusters of Malay culture, for example marked by several dialects which have similarities, and the use of 'sekapur sirih' in every traditional ceremony, as a symbol of respect and acceptance for the arrival of invited guests.

b. Influence of Chinese Culture

The Lampung community in its customs and culture does not recognize the existence of a fan (kipas), so that in the Nyambai cultural performances that use fan property is the result of acculturation of Chinese culture. Furthermore, the traditional clothes of Lampung people in the Coastal area are a combination of red and golden yellow. 


\section{c. Influence of Arab Culture}

The influx of Arabic culture through Islamic teachings in the Coastal Area of Lampung, affects all forms of people's lives, religious values, customs, and the behavior of their communities. In the culture of flogging, the value of the teachings of Islam is very clear, as seen in the clothes used by dancers must cover their genitals and there are boundaries between male and female dancers who are considered not their muhrim.

\section{d. Dutch influence}

The arrival of the Dutch into the Lampung coast affected the pattern of people's lives, in the culture of flogging the influence was very strong, among others, the differentiation of lower class and upper class people, so that dancers from noble envoys got a more respectable position, using traditional attire wearing footwear, and sit in the chair. Very different from dancers from ordinary society. Classification of classes and social status in Coastal communities is a form of Dutch government at that time indicated to divide society.

Diagram 1. Establishment of Nyambai Culture That is Influenced by Its Environment

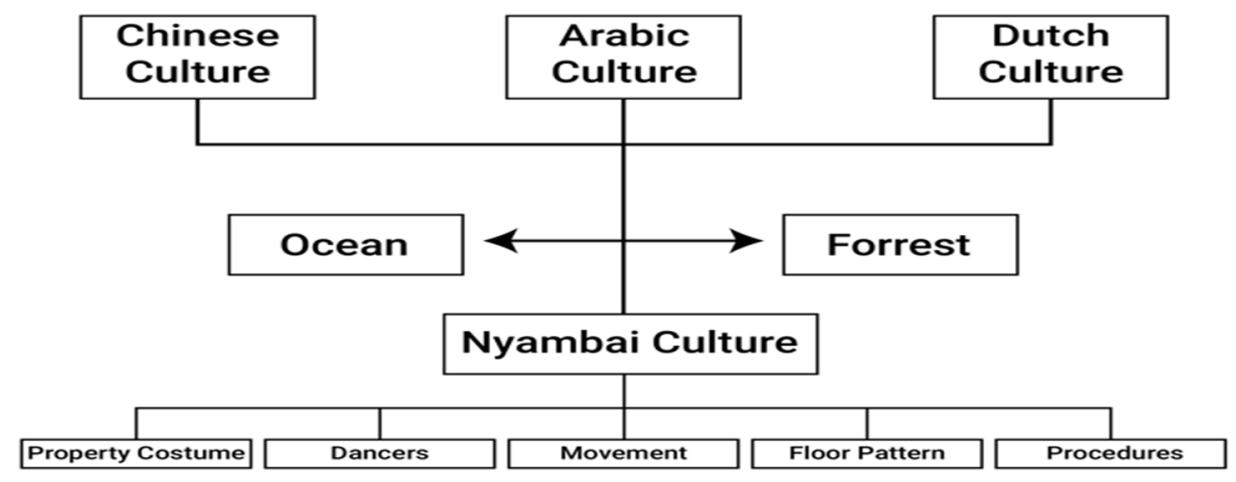

\subsection{Structure of Relationship Concept of the Function of Waving Culture}

Structuralism links the inner structure reality contained in all aspects of human life. This theory view consists of two sides, namely: structure and system. According to Levis Strauss [10] theories that can reveal a system or pattern that occurs in one physical and non-physical community. This theory explains how culture through the study of behavior, the behavior is expressed to get the concept behind it. This concept is expected to be realized through a comprehensive study of behavioral observations including the existence of myths in the form of complex stories that reveal human existence. Using the structuralism theory of Levis Strauss will show how the structural relations in the Nyambai and the Lampung kinship system, show the existence of certain structures in Nyambai culture, this study seeks to reveal what relationships are present in the structure of performances and kinship structures that has enabled Lampung people to build symbolic nets, to finally be able to open cultural values and cultural identities of Lampung people. The Nyambai structure can be seen from the relationships that occur between functions, forms and meanings that will open the concept behind it from the object of the waving culture. 
Table 1. Relations of Lampung Coastal Society With Structure and Function

\begin{tabular}{|c|c|c|c|c|}
\hline No & $\begin{array}{l}\text { Coastal Society } \\
\text { Relationship }\end{array}$ & Form & Meaning & $\begin{array}{l}\text { Structure inside } \\
\text { function }\end{array}$ \\
\hline 1. & Men - God & $\begin{array}{c}\text { Hadra, Dziker, } \\
\text { Nyambai }\end{array}$ & Baffle & Religious \\
\hline 2. & Men - Nature & $\begin{array}{l}\text { Dance Movement } \\
\text { (Mampang } \\
\text { Kapas) } \\
\text { Eagle Lurks } \\
\text { (Elang mengintai } \\
\text { Kekindai) }\end{array}$ & $\begin{array}{l}\text { Nature } \\
\text { Usage }\end{array}$ & $\begin{array}{c}\text { Natural Power } \\
\text { Taking a good } \\
\text { care of ecosystem }\end{array}$ \\
\hline \multirow[t]{2}{*}{3.} & Men - Men & Interactions & Discussion & Hospitality \\
\hline & & $\begin{array}{c}\text { Floor pattern facing } \\
\text { Penari } \\
\text { Men and Woman }\end{array}$ & $\begin{array}{l}\text { Face to face } \\
\text { In pairs }\end{array}$ & $\begin{array}{c}\text { Balance } \\
\text { Working together, } \\
\text { Fertility }\end{array}$ \\
\hline
\end{tabular}

The Nyambai cultural performance in addition to getting influence from outside culture also reflects a strong relationship between the community and the surrounding environment, some names of various dance movements take from natural terms, such as animals and plants. These natural names are a symbol of the power of nature that gives life to society. The eagle's motion lurks symbolizing strength, the motion of the scans describes the flapping of the wings of an eagle, and the movement of cotton symbolizes the power of a towering cotton tree. From the names of these various movements, Coastal communities are inspired by the forces of nature. Betel symbolizes togetherness, brotherhood and strength. While the floor pattern used is straight and horizontal lines symbolizing balance, there is a relationship between humans and God, humans with nature and humans with each other.

The relation of the Lampung Coastal community to its God is reflected in daily life, even when in traditional activities, Islamic teachings are still applied. Before the custom event begins, community activities are filled with dhikr by chanting the holy verses of the Koran. Coastal communities apply and adhere to the teachings of Islam with the truth, when in culture flogging every male and female dancer is distinguished by a seat and given a baffle, indicating not the muhrim (relatives), therefore that the dancers may not be close together and touch. In everyday life this social order is called a sequel, these norms are still held firmly by the Coastal community, to maintain the association of youth and young women in the community so as not to deviate. [11] Respect for nature is a way of thinking where humans have a moral obligation to respect nature. Nature has the right to be respected, not only because human life depends on nature, however it is because of the ontological reality that humans are an integral part of nature and depend on nature. Human relations with each other, indicated by the activities of gathering, deliberating, mutual cooperation in every activity carried out in the community.

\section{CONCLUSION}

The results of the study showed that as a form of acculturation, culture became a new identity for art forms in the Coastal region to adjust the natural conditions and the surrounding 
environment. Coastal Art is very influential on the life behavior of its people, the relation of the concepts of function, form, and meaning of the flogging culture implicitly or explicitly influences the pattern of human actions in daily life, maintaining the relationship between humans and God, with nature, and with each other.

\section{ACKNOWLEDGMENT}

The author expresses his gratitude for the assistance of LPDP as the scholarship provider to the author until he can complete the study period.

\section{REFERENCES}

[1] C. R. Ningrum, "Fungsi tari nyambai pada upacara perkawinan adat nayuh pada masyarakat saibatin di pesisir barat lampung," JOGED J. Seni Tari, vol. 10, no. 2, pp. 533-546, 2017.

[2] A. Andika and B. V. Nurdin, "Makna Adat Nyambai dan Perubahannya," Sosiol. J. Ilm. Kaji. Ilmu Sos. dan Budaya, vol. 14, no. 1, 2014.

[3] R. Hilmanto, Etnoekologi. Bandar Lampung: Universitas Lampung, 2010.

[4] M. Takari, "Bahasa Melayu dalam Konteks MEA," in Seminar Bahasa Melayu sebagaiBahasa ASEAN, 2017.

[5] E. Sugiarto, "Ekspresi Visual Anak-Anak Kawasan Tanjung Mas Semarang Dalam Kajian Ekologi-Budaya Pesisir,” Imajin. J. Seni, vol. 7, no. 1, pp. 9-16, 2014.

[6] E. Kusumastuti, "Laesan sebuah Fenomena Kesenian Pesisir : Kajian Interaksi Simbolik antara Pemain dan Penonton," Harmon. J. Arts Res. Educ., vol. 7, no. 3, 2006.

[7] M. Fajrie, "Gaya Komunikasi Masyarakat Pesisir Wedung Jawa Tengah," NJECT (Interdisciplinary J. Commun., vol. 2, no. 1, pp. 53-76, 2017.

[8] B. Fauzy, Antariksa, and P. Salura, "Memahami Relasi Konsep Fungsi, Bentuk dan Makna Arsitektur Rumah Tinggal Masyarakat Kota Pesisir Utara di Kawasan Jawa Timur,” Dimens. (Jurnal Tek. Arsitektur), vol. 38, no. 2, pp. 79-87, 2012.

[9] M. B. Miles and J. Huberman A. Michaek. Saldaña, Qualitative Data Analysis A Methods Sourcebook, 3rd ed. Los Angeles: Sage, 2017.

[10] H. S. Ahimsa-putra, "strukturalisme Levi-Strauss untuk Arkeologi Semiotik," Humaniora, vol. 11, no. 3, pp. 5-14, 1999.

[11] S. Rusanen, P. Malinen, and K. Rintakorpi, "Art, Agency and Environment-the Perspectives of Youth Culture and the Culture of Children," Procedia - Soc. Behav. Sci., vol. 45, pp. 407-415, 2012. 